\title{
WISATA MINAT KHUSUS: \\ 'Menguak' Kehidupan Masyarakat Jawa Kuna \\ Melalui Relief Candi
}

\section{SPESIFIC INTEREST TOURISM: Revealing the Ancient Java Community Daily Life Through the Temple Reliefs}

\author{
T.M. Hari Lelono \\ Balai Arkeologi Yogyakarta \\ harilono@gmail.com
}

\begin{abstract}
There are still some tourism potentials not yet entirely discovered to the public and to the tourists, specifically to the special interest type of these tourists. The potential object will be discussed on this paper relates to the cultural content which is carved over the temple's walls through the decorative reliefs reflecting the reality or any information about the temple itself and its era. Through the reliefs, many information about the daily live of the ancient Javanese people are revealed. Besides that, the reliefs also describe the species variety of vegetation and animal, the clothes and its supporting ornaments as well as the story or fable which is containing of the original cultural values of Indonesia including the moral messages which give our nation an identity and integrity. The moral values or contents should be offered to the tourists so they could understand the original culture of Indonesia by not only enjoying the physical aspect of any objects (tangible) but more over the intangible aspect which gives a spirit into those objects.
\end{abstract}

Keywords: Special Interest Tour, Reliefs, Ancient Javanese

\begin{abstract}
ABSTRAK
Masih banyak potensi obyek pariwisata yang terpendam belum diungkapkan pada publik dan wisatawan, khususnya wisatawan minat khusus. Obyek tersebut berupa budaya materi candi dengan hiasan-hiasan relief yang mengelilinginya dan informasi pada gambar-gambar relief tersebut. Melalui relief candi banyak hal dapat diungkapkan tentang kehidupan masyarakat pada masa Jawa Kuna. Informasi berupa jenis-jenis flora, fauna jenis pakaian dengan kelengkapannya, serta cerita dan dongeng yang mengandung nilai-nilai kultural asli Indonesia, berupa pendidikan moral dan budi pekerti yang perlu diketahui oleh khalayak Indonesia sebagai identitas dan jatidiri Bangsa. Materi tersebut, dapat ditawarkan pada wisatawan untuk mengetahui tentang "budaya" asli Indonesia, sehingga bukan hanya menyaksikan bentuk-bentuk fisik (tangible) tetapi juga bentuk-bentuk (intangible), sebagai 'roh' yang dapat menjelaskan secara holistik.
\end{abstract}

Kata Kunci: Wisata Minat Khusus, Relief, Jawa-Kuna.

\section{PENDAHULUAN}

Indonesia sebagai salah satu negeri kepulauan yang letak astronomis sangat strategis $6^{\circ} \mathrm{LU}-1^{\circ} \mathrm{LS}$ dan $95^{\circ} \mathrm{BT}-1^{\circ} 141^{\circ} \mathrm{BT}$, saat ini telah menjadi primadona wisatawan mancanegara untuk melihat dan menikmati keindahan alam dan kultur 
Indonesia. Dalam konteks tersebut, di tahun 2010 jumlah kunjungan wisatawan mancanegara (wisman) mencapai 7 juta. Wajar jika Kementerian Kebudayaan dan Pariwisata menetapkan target kunjungan wisatawan ke Indonesia pada tahun 2011 sekitar 7,7 juta orang. Dalam upaya mencapai target tersebut, pemerintah mempromosikan Indonesia melalui slogan "Wonderful Indonesia" yang menggambarkan daya tarik masyarakatnya, budayanya, makanannya, investasinya, dan alamnya. Sementara tema pariwisata 2011 yaitu "Eco, Cultural, and MICE". Eco merupakan bentuk kepedulian pariwisata Indonesia terhadap lingkungan. Culture menjadi harta dan kekuatan Indonesia yang memiliki kekayaan seni budaya beraneka ragam dari Sabang hingga Merauke. MICE (meeting, incentive, convention, dan exhibition).

Kenaikan jumlah kunjungan wisatawan di tahun 2011 dan di tahun-tahun selanjutnya merupakan usaha yang realistis dengan melakukan penataan sumberdaya alam, penataan kawasan dan peningkatan sumberdaya manusia (SDM) yang handal. Hal tersebut di depan seiring dengan pariwisata akan terus meningkat dari waktu ke waktu, dilihat dari berbagai indikator. Dari segi kedatangan wisatawa internasional, dari tahun 1950 sampai 2010 peningkatan jumlah kunjungan wisatawan internasional bergerak dari 25 juta sampai 940 juta orang, dengan pertumbuhan setiap tahunnya rata-rata $6,2 \%$ (UNWTO, 2011). Bahkan diperkirakan pada tahun 2020 jumlah wisatawan dunia akan mencapai 1,6 miliar kunjungan. Dengan melihat prediksi tersebut tidak mustahil negaranegara berkembang (termasuk Indonesia) juga dapat menikmati irisan kue pariwisata tersebut (Andriani: 119, 2011).

Salah satu hal yang menarik menjadi perhatian dalam tema pariwisata Indonesia 2011, adalah pada aspek kultur, karena Indonesia terdiri dari bermacam suku. Kekayaan kultur Indonesia sudah sejak dahulu kala selalu menjadi daya tarik untuk diketahui dan dipelajari oleh banyak orang dari pelbagai penjuru dunia. Hal tersebut sangat unik dan spesifik mengingat alam flora-fauna Indonesia yang bercirikan daerah tropis. Alam tropis tersebut berpengaruh kuat dalam kultur masyarakat Indonesia dari Sabang hingga Merauke. Oleh karena itu, potensi budaya yang telah ada tersebut dapat menjadi salah satu modal untuk di promosikan kepada wisatawan mancanegara maupun domestik (wisatawan Nusantara/ Wisnus).

Salah satu sumber informasi yang menarik bagi wisatawan minat khusus adalah tinggalan budaya materi berupa candi-candi sebagai warisan budaya Hindu-Budha. Pengaruh budaya Hindu-Budha sampai kini masih dirasakan di dalam kehidupan seharihari masyarakat, khususnya di Jawa dan Bali. Budaya tersebut berupa tinggalan materi (tangible) dan budaya non-materi (intangible), sebagai salah satu contoh dalam konteks judul di depan, adalah tinggalan budaya materi berupa bangunan candi dengan relief yang menghiasinya. Sebenarnya melalui panil-panil relief tersebut, banyak informasi pengetahuan yang dapat digali dari keterangan-keterangan dan cerita-cerita yang oleh sebagian masyarakat kita masih cukup dikenal. Melalui gambar-gambar tatahan pada panil dapat diketahui tentang aspek kehidupan nenek moyang di masa lalu dengan aneka macam pesan-pesan moral dan etika yang dapat diacu sebagai dasar dari perilaku masyarakat sehari-hari. Oleh karena itu, candi sebagai obyek wisata tidak hanya dilihat dari segi bangunan fisik (etik) semata, tetapi terdapat hal-hal yang bersifat emik yang digunakan untuk menjelaskan hubungan antara panil (gambar-gambar) relief dengan kehidupan sekeliling masyarakatnya. sehingga memberikan "roh" yang menarik untuk diketahui oleh wisatawan khususnya minat khusus dan masyarakat luas.

Selama ini wisatawan yang berkunjung ke objek-objek cagar budaya hanya untuk datang melihat bangunan dari sisi arsitekturnya, tetapi belum memperoleh gambaran lengkap tentang hal-hal yang intangible. Pengetahuan yang mereka peroleh hanya gambaran umum dari para pemandu wisata yang tidak/ belum terlatih sebagai pemandu (guide) yang profesional. Sementara itu, bangunan candi biasanya dilengkapi dengan berbagai macam hiasan pada bidang yang kosong atau pada panil-panil khusus yang disediakan untuk media menggambarkan relief tertentu. Hal itulah yang menjadi permasalahan dalam makalah ini, yakni wisatawan belum memperoleh informasi lengkap 
tentang 'roh' yang ditatahkan dalam panil-panil relief, padahal melalui relief berbagai aspek budaya/ kehidupan masa lalu dapat direkontruksi.

Oleh karena itu, melalui relief candi masih banyak informasi yang dapat diberikan kepada para wisatawan minat khusus tentang budaya tangible dan intangible yang merupakan jatidiri bangsa, sebagai bukti kemajuan peradaban Indonesia asli, utamanya dalam menanamkan nilai-nilai kehidupan bagi umat manusia yang selaras dengan alam lingkungannya. Melalui relief candi diharapkan dapat menambah keingin-tahuan wisatawan akan nilai-nilai positif, filosofi tentang kehidupan masyarakat pada masa Jawa Kuna. Bermacam potensi dan daya tarik tersebut, menyebabkan wisatawan akan memperoleh pengetahuan yang lengkap/ holistik tentang kebudayaan Indonesia dan semakin betah untuk tinggal lebih lama di Indonesia.

\section{DATA ARKEOLOGIS SEBAGAI DAYA TARIK WISATA}

Arkeologi Indonesia dibentuk pada masa pemerintahan Hindia Belanda, pada tanggal 14 Juni 1913 dengan nama Oudheidkundige Dienst in Nederlansch-indie. Pada mulanya menangani masalah dalam konteks kesenian, etnografi, arsitektur, dan filologi. Pada masa awal setelah kemerdekaan Republik Indonesia sampai kini di kalangan masyarakat luas dikenal dengan nama 'purbakala'. Dalam usianya yang ke 98 purbakala sejak mulai berdirinya lembaga tersebut telah mengalami masa-masa pasang-surut. Dalam perkembangannya, objek dan kajian arkeologi menjadi semakin kompleks pada berbagai aspek kajian. Arkeologi Indonesia pada dasarnya dapat dikelompokkan ke dalam empat periodesasi/ kajian, yakni; Arkeologi Prasejarah, Arkeologi Hindu-Budha (masa Klasik), dan Arkeologi masa Islam/ kolonial, selain itu masih dibantu oleh disiplin ilmu terkait lainnya seperti misalnya antropologi, geografi, dan geologi. Berkaitan dengan periodesasi tersebut dapat dibedakan ke dalam: 1) Arkeologi Prasejarah, mengkaji fosil-fosil flora dan fauna dengan lingkungan purba dan masa manusia belum mengenal tulisan, hidupnya masih berpindah-pindah dari satu tempat ke tempat lain untuk mencari sumber makanan, sebagai contoh adalah hunian gua-gua dan alat-alat dari bahan lithic (batu); 2) Arkeologi Hindu-Budha (masa Klasik), yakni masa pengaruh kebudayaan Hindu-Budha masuk ke Indonesia, sebagai contoh adalah situs-situs bangunan candi, permukiman masa Jawa kuna dan Majapahit; 3) Arkeologi Islam dan Kolonial, adalah berupa pengaruh kebudayaan Islam dan kolonial yang masuk ke wilayah Nusantara dengan berbagai tinggalan berupa masjid, makam, keraton, serta tinggalan bangunan kolonial, benteng-benteng dan gua-gua jepang. Selain ketiga kajian tersebut, pada saat ini mulai dikembangkan potensi arkeologi bawah air (under water archaelogy) ; 4) Arkeologi Bawah Air, melakukan kajian budaya maritim serta tinggalannya berupa kapal tenggelam sejak masa prasejarah sampai dengan masa kolonial.

Dari empat bidang kajian tersebut, masing-masing memiliki potensi untuk menambah daya tarik pariwisata, namun dalam hal ini yang secara khusus akan dibahas hanya pada arkeologi masa Klasik (Hindu-Budha). Pengaruh budaya ini walaupun sudah terbungkus oleh budaya yang baru, tetapi beberapa substansinya masih dapat diketahui dari perilaku kehidupan masyarakat sehari-hari, berupa adat-istiadat, upacara tradisional, kesenian, bahasa dan tradisi hidup yang menyangkut proses kehidupan manusia sejak lahir, anak, dewasa dan mati (life circle).

Sejak Indonesia memproklamirkan Kemerdekaannya pada tanggal 17 Agustus tahun 1945, informasi arkeologis tentang pemanfaatan dan pengembangannya masih kurang gaungnya, apalagi untuk dimanfaatkan oleh masyarakat. Di era globalisasi dan informasi teknologi yang canggih, merupakan momentum yang tepat 'dunia arkeologi' untuk mensosialisasikan hasil-hasil kajian, penelitian selama ini kepada seluruh masyarakat dari berbagai lapisan, baik domestik maupun mancanegara, melalui dan memanfaatkan berbagai macam media informasi yang ada. Hal tersebut seiring dengan dinamika masyarakat yang selalu ingin berkembang, mulai tumbuh kesadaran untuk mencari jatidirinya melalui warisan budaya yang ditingalkan oleh nenek moyang berupa budaya materi dan yang berupa nilai-nilai. Oleh karena itu, kajian-kajian arkeologis yang 
selama ini bersifat ilmiah dan ilmu pengetahuan semata, harus disesuaikan dengan kebutuhan/ kepentingan masyarakat dan stakeholders. Tujuan akhir dari sosialisasi tersebut, salah satunya diharapkan dapat meningkatkan pendapatan ekonomis melalui dunia pariwisata.

Selama ini wisatawan domestik maupun mancanegara, jika mengunjungi situs-situs hanya melihat bentuk arsitektural/ esksotisme bangunannya, tetapi belum memperoleh informasi yang ada di 'balik' arsitektur dan ragam hias candi tersebut. berupa ornamenornamen hiasan berupa daun-daunan, sulur-suluran, arca-arcanya. Dari seluruh ragam hias tersebut dapat diketahui tentang nilai-nilai simbolis, religius dan bahkan dapat digunakan untuk memberikan penjelasan tentang kehidupan masyarakat pada masa Jawa kuna. Berkaitan dengan hal yang bersifat intangible tersebut, beberapa masyarakat masih melakukan tradisi dengan meletakkan sesajian yang terdiri dari bunga-bungaan (kembang), rokok, nasi golong (nasi merah, kuning, putih) dan lain-lainnya pada bangunan candi, berkaitan dengan ritual dalam sistem kepercayaan yang diyakininya. Perilaku tersebut, dengan meletakkan sesajian pada tempat-tempat tertentu menandakan, bahwa kuatnya hubungan emosional antara masyarakat yang hidup di sekitarnya dengan bangunan candi tersebut.

Permasalahan penting yang selama ini sering terjadi, adalah dala rangka arkeologi Go Public belum melakukan sosialisasi secara gencar dengan memanfaatkan media cetak/ elektronik yang ada secara terus-menerus, khususnya untuk merubah image dunia pariwisata tentang tinggalan cagar budaya yang hanya dilihat dari sisi bentuk lahiriah (fisik) semata. Padahal dari satu buah candi saja, banyak informasi yang dapat digali tentang nilai-nilai simbolis gambar, model ukiran, susunan bangunan (kaki candi, badan candi, kemuncak/ puncak candi) dan hiasan relief. Dalam konteks ini, untuk pemanfaatan dunia pariwisata, adalah data arkeologis dapat menjadi satu-satunya acuan untuk memberikan penjelasan berupa 'roh', sehingga wisatawan tidak hanya melihat fisik bangunan, tetapi juga memperoleh informasi yang menarik dan lengkap tentang sejarah dan kehidupan masyarakat Jawa kuna di masa lalu.

\section{PANIL RELIEF CANDI SEBAGAI 'ROH'}

Candi sebagai salah satu obyek wisata yang banyak dikunjungi oleh wisatawan mancanegara maupun nusantara. Secara arsitektural maupun latar kulturalnya memiliki keunggulan dan keindahan. Keindahan tersebut merupakan hasil budaya yang bernilai tinggi dan dilakukan dengan penguasaan teknologi yang bernilai tinggi dengan menggunakan bahan batu (andesit, bata merah). Sebagai bangunan suci, candi-candi yang besar atau yang memiliki status penting biasanya dilengkapi dengan berbagai hiasan di bagian kaki candi, badan/ tubuh candi berupa motif hiasan sulur-sulur daundaunan dan panil relief yang mengandung unsur cerita maupun non-cerita. Mengenai penggambaran panil relief, terdapat sekurangnya tiga jenis, antara lain:

\section{Relief cerita}

Panil-panil relief pada candi-candi yang ditemukan di daerah Jawa Tengah maupun Jawa Timur, substansi ceritanya ada persamaannya, tetapi teknik pentatahan gambarnya terdapat perbedaan yang mencolok. Teknik penggambaran relieh candi periode Jawa Tengah/ DI. Yogyakarta secara tiga dimensi, sedangakn di Jawa Timur hanya dua dimensi. Persamaan dalam unsur ceritanya seperti cserita: Ramayana, Garudya, Sidharta Gauthama (Budha), Bubuksah Gagangaking, dan cerita-cerita Tantri. Sedangkan selain cerita tersebut, di Jawa Timur juga dipahatkan unsur cerita Panji, seperti kisah Raden Panji Asmarabangun dengan Dewi Sekartaji. Panji, yang diyakini oleh para peneliti budaya, sebagai seorang tokoh lokal yang sangat berpengaruh sekitar abad ke XV Masehi. Cerita Panji adalah cerita Jawa asli yang kemudian menyebar ke berbagai wialayah Nusantara (Bali, Sunda, Lombok, Kalimantan, Palembang, Melayu) serta berbagai negara di daratan Asia Tenggara. Hal ini merupakan aspek penting yang perlu disosialisasikan sebagai alternatif cerita 
wayang yang selama ini hanya menjadi dominasi Mahabarata dan Ramayana yang datang dari India (Nurcahyo, ed. 2009: 1). Sementara itu, tokoh-tokoh dewa yang digambarkan biasanya dewa (Brahma, Wisnu Siwa), Sang Sidharta Gautama (Budha), dan Panji. Pengggambaran tokoh cerita yang menarik adalah, dengan digambarnya cerita fabel dengan tokoh-tokoh yang diperankan oleh binatang. Cerita fabel yang terkenal tersebut di antaranya, seperti: kura-kura, kancil, kerbau, buaya, burung, dan ular.

\section{Relief non-cerita}

Gambar relief non-cerita biasanya dipahatkan pada bagian kosong dikaki atau tubuh candi, berupa garis-garis geometris dalam bentuk vertikal atau horisontal, lingkaran, sulur-sulur tumbuhan, dan pohon-pohonan. Selain itu dapat berupa hiasan flora dan fauna yang distilir dan mengandung makna simbolis, berkaitan dengan masalah kesuburan. Gambar-gambar tersebut ditatahkan dalam konteks religius dan sebagai penambah nilai estetika, agar bangunan tersebut kelihatan semakin raya/ indah dengan berbabagai macam ukiran.

\section{Relief flora/ fauna dan mahluk-mahluk kayangan}

Merupakan gambar-gambar dalam bentuk flora, fauna dan mahluk aneh. Penggambaran bermacam jenis flora dan fauna tetapi distilir, sehingga bentuk dan jenis flora/ fauna tersebut tidak jelas. Sebagai contoh penggambaran burung, kambing dengan tanduk, kuda bersayap dan lain-lainnya. Sedangkan bentuk manusia, digambarkan dalam wujud manusia aneh dan tidak proporsional seperti, cebol (kerdil), kurus, gemuk, dan bulat. Penggambaran dalam bentuk-bentuk yang aneh tersebut, sebenarnya mengandung makna-makna simbolis, seperti hal-hal yang tidak normal sebenarnya memiliki fungsi dan makna penting serta hubungan harmonis antara manusia dengan lingkungannya, atau mengandung pesan-pesan tentang kelestarian alam dan ekosistem.

Dari seluruh relief cerita maupun non-cerita di depan, dapat memberikan gambaran tentang kehidupan masyarakat Jawa kuna, seperti: 1) Alat-alat transportasi (gerobag, pedati, kereta, kuda, kerbau, gajah, perahu berlayar rangkap dengan tiangtiang tinggi berlapis, perahu bercadik dan jembatan bambu), dapat dilihat di Candi Borobudur; 2) Alat pertanian (alat bajak, cangkul, kerbau, dan sawah); 3) Pengairan (bendungan, kanal-kanal, dan saluran irigasi) dapat dilihat di koleksi relief Museum Trowulan, Mojokerto; 4) Permukiman (bentuk-bentuk tata ruang desa/ dusun, kota kerajaan, dan bentuk rumah tinggal), salah satu gambar tersebut dapat dilihat pada relief koleksi Museum Trowulan, Mojokerto; 5) Gambaran sosial/ ekonomi (pornografi, kejahatan, aktivitas pasar dan penyadapan gula aren/ kelapa) salah satunya dapat dilihat di Candi Surawana, Pare Kediri).

Dari gambar panil relief yang ditemukan tersebut, beberapa di antaranya masih dapat kita temukan digunakan oleh masyarakat tradisional atau yang lokasinya jauh dari perkotaan sebagai alat bantu dalam aktivitas sehari-hari dalam kegiatan bertani, berniaga dan nelayan, asebagai benda atau data etnografis. Hal tersebut menandakan, bahwa dalam beberapa bagian tradisi yang digunakan oleh nenek moyang pada masa Jawa kuna, masih kita warisi sampai pada masa kini.

Berkaitan dengan hal tersebut, Balai Arkeologi Yogyakarta pada tahun 1996 - 1999 melakukan penelitian eksploratif tentang bermacam jenis flora dan fauna yang dipahatkan pada candi-candi di Daerah Istimewa Yogyakarta, Jawa Tengah dan Jawa Timur. Dari hasil penelitian dapat diketahui tentang domestikasi flora/ fauna asli Indonesia, dengan pengetahuan tersebut, mereka akan mengetahui unsur-unsur budaya lokal/ asli Indonesia. Muatan lokal Indonesia, biasanya bercirikan pesan-pesan moral dan etika, seperti singa (Afrika) yang bukan asli Indonesia, sedangkan mong (harimau tutul, loreng) adalah asli Indonesia. Dalam kesimpulan penelitian tersebut, diperoleh data yang menggambarkan tentang domestikasi, pemanfaatan tenaga, sebagai piaraan, sebagai 
binatang buruan, dikonsumsi, dan sebagai simbol pada cerita binatang (fabel) serta peranan simbolik keagamaan lainnya (Siswanto, 2000: 25).

Beberapa contoh cerita fabel yang menarik, seperti di Daerah Istimewa Yogyakarta (DIY), Jawa Tengah dan Jawa Timur, diantaranya adalah: DI. Yogyakarta candi induk Prambanan (Brahma, Wisnu dan Siwa); Jawa Tengah Candi Borobudur dan mendut, serta; Jawa Timur di Candi Penataran, Surowono, dan Jago. Beberapa contoh relief dari candi-candi tersebut letak dan akses untuk menuju ke lokasi cukup mudah, karena daerah sekitarnya sudah disiapkan bermacam infra struktur sarana maupun prasarana wisata oleh pemerintah daerah setempat. Memasuki sebuah candi yang berisikan panilpanil relief, ada yang berjalan dengan arah jarum jam (pradaksina) dan ada yang harus mengirikan candi/ berlawanan arah jarum jam (prasawyam). Berikut ini beberapa contoh relief candi yang menarik untuk dipromosikan kepada wisatawan minat khusus, namun untuk mengetahui jalan cerita panil-panil relief, pengunjung harus berjalan mengelilingi Candi Pendapa Panataran, berlawanan arah dengan jarum jam dalam bahsasa Jawa Kuna (prasawyam). Tentunya masih banyak cerita relief yang belum diketahui maksud dan ceritanya, karena memerlukan suatu kajian relief cerita yang dipadukan dengan karya-karya sastra kuna yang dituliskan pada: prasasti, lontar-lontar dan naskah-naskah lainnya, seperti berdasarkan pada Kitab Tantri, Ramayana, Kresnayana, Arjuna Wiwaha, Sri Tanjung, dan lain-lainnya.

Beberapa panil relief yang menarik untuk diketahui:

\section{Candi Borobudur}

Letak astronomis Candi Borobudur 3 23' 42.34" BT dan 7 36' 29.67" LS. Candi peninggalan Dinasti Syailendra yang berkuasa di Jawa Tengah sekitar abad VIII M. Bahan yang digunakan untuk bangunan candi seluruhnya menggunakan batu andesit dengan porositas yang rapat (halus). Bangunan berlatar agama Budha berlantai empat ini, disetiap lantainya dihiasi dengan relief. Hiasan relief pada masing-masing lantai dari lantai satu sampai empat berisikan cerita; lantai 1 mengisahkan cerita Lalita-Awadana, lantai 2 Gandawyuha, lantai 3 Maitreya, dan lantai 4 Samantabadra. Semua cerita tersebut secara garis besar mengisahkan perjalanan Sang Budha Gaotama dari sejak kecil, dewasa, dan mengajarkan keyakinannya sebagai Sang Budha. Pada bagian kaki candi paling bawah dan belum banyak dketahui oleh wisatawan, karena sebagian masih ditutup dengan tanah, adalah sebuah misteri cerita Maha Karmawibhangga. Mengisahkan perjalanan perbuatan kehidupan manusia di bumi yang berisikan tentang hukum sebab-akibat atau yang dikenal hukum karma. Setiap perbuatan yang dilakukan di bumi baik perbuatan baik maupun kejahatan, kelak akan diterimanya di akhirat. Oleh karena itu, dengan melihat dan menghayati ajaran dalam gambar relief tersebut menjadi kontrol setiap tindakan manusia selama hidupnya di bumi.

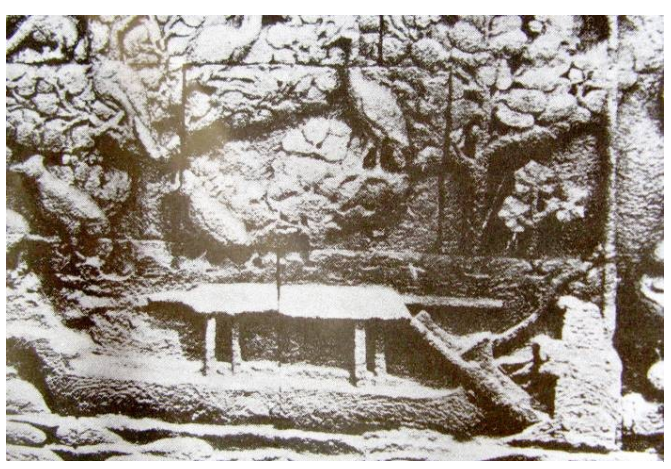

Foto 1. Salah sat relief Candi Borobudur. Alat transportasi air untuk jarak dekat dengan perahu kayu menggunakan dayung dan atap sebagai tempat berteduh. Dok Balar YK.
Dari seluruh adegan dalam panil-panil relief dari lantai satu sampai dengan lantai empat, sangat menarik untuk diinformasikan kepada wisatawan yang berminat ingin mengetahuinya. Dalam pahatan adegan cerita tersebut, menggambarkan kehidupan masyarakat masa Jawa kuna dengan bermacam sarana dan prasarana untuk menopang kehidupan, seperti alat-alat transportasi, perahu, gerobak, kuda, gajah, dan masih banyak lagi yang lainnya. Dalam foto (1) merupakan salah satu alat transportasi air, perahu berukuran kecil menggunakan atap pada bagian tengah untuk berteduh penumpang, yang digerakkan dengan tenaga dayung/ dikayuh. Pada bagian 
sisi perahu terdapat cadik, berfungsi sebagai penyeimbang perahu untuk melaju menyibak gelombang air. Perahu bercadik saat ini masih banyak dijumpai dan digunakan oleh para nelayan untuk mencari ikan, penyeberangan dan keperluan transportasi air lainnya. Gambar tersebut memberikan bukti kepada kita, bahwa perahu dengan bentuk dan teknologi seperti itu telah digunakan sekurang-kurangnya sejak abad ke VIII Masehi oleh masyarakat Jawa kuna dan hingga kini masih digunakan di perairan Nusantara. Selain perahu bercadik, dipahatkan perahu-perahu yang menggunakan tiang-tiang tinggi dengan layar yang berlapis-lapis. Melihat bentuknya, perahu jenis ini termasuk perahu yang besar untuk melintasi samudera, antar negara dan digunakan untuk mengangkut perdagangan oleh armada-armada besar.

\section{Candi Mendut}

Letak astronomis Candi Mendut 3 25' 15.53" BT dan 7 36" LS, merupakan peninggalan abad IX -- X Masehi. Candi dengan orientasi bangunan menghadap ke arah barat-timur tersebut, pada kedua sisi luar tangga masuk candi masing-masing dihiasi dengan relief. Candi yang menggunakan bahan batu andesit dan teknik pengerjaan yang halus dan indah tersebut, menggambarkan figur-figur manusia mengenakan model pakaian dengan telanjang dada dan model cancut pada bagian bawah. Model tersebut kemungkinan lazim digunakan pada masa kehidupan masyarakat Jawa-Kuna.

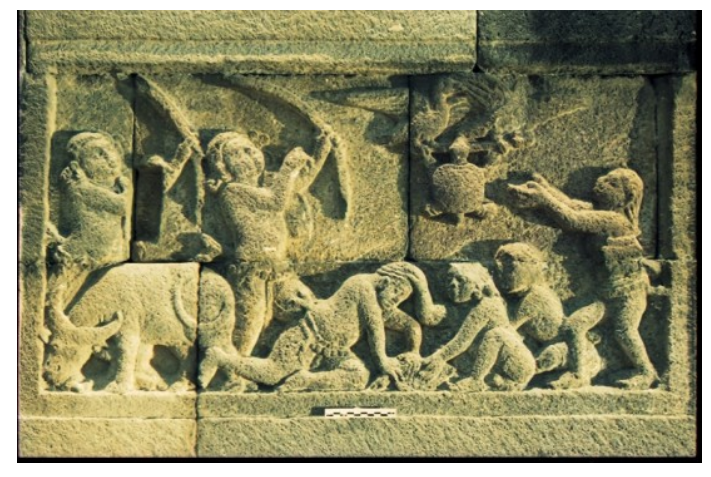

FOTO 2. Relief pada tangga masuk Candi Mendut. Digambarkan sekelompok pengembala sedang mengolok-olok kura-kura yang diterbangkan oleh dua kawanan burung belibis. Dok Balar-YK.

Candi yang terletak di Kabupaten Magelang, Jawa Tengah, bercorak keagamaan Budhis, merupakan tinggalan sekitar abad ke IX - X Masehi. Jika masuk ke dalam candi harus melalui tangga, pada sisi luar tangga sebelah selatan terdapat panil relief Cerita Tantri yang sangat terkenal pada masa Jawa Kuna. Dalam cerita Tantri digambarkan tentang tuntunan hidup antar sesama manusia, flora-fauna dan alam lingkungannya, sesuai dengan ajaran Budhis. Penggambaran kehidupan manusia sehari-hari menjadi pesan penting yang ingin disampaikan melalui relief-relief tersebut, tentang moral, etika dan harmonisasi kehidupan manusia. Gambar pahatan dengan teknik tiga dimensi tersebut, semakin berkesan hidup/ alami dan indah dipandang mata, bahkan kadang tokoh-tokoh yang digambarkan dalam bentuk (fabel) penuh dengan suasana yang jenaka. Dalam foto (2), relief derngan lebar $100 \mathrm{~cm}$ dan tinggi $55 \mathrm{~cm}$ tersebut digambarkan adegan sekelompok pemburu dan pengembala kerbau sedang mengolok-olok seekor kura-kura yang diterbangkan oleh dua ekor burung belibis. Gambar tersebut merupakan cerita dongeng (fabel) yang didengarkan pada anak-anak kecil menjelang tidur dan masih didongengkan sampai sekitar akhir tahun 1970-an (Lelono, 1999: 21).

\section{Candi Penataran, Kabupaten Blitar}

Candi Penataran terletak di Desa Penataran, Kecamatan Nglegok, Kabupaten Blitar, Jawa Timur. Candi menggunakan batu andesit berwarna agak keputihan berlatar keagamaan Siwa, diduga dibangun sekitar abad XIII - XV Masehi. Candi Penataran terdiri dari tiga bagian utama, pada bagian depan dinamakan Candi Pendopo, dibagian tengah terdapat bangunan candi.-candi dan paling belakang merupakan candi induk yang terdiri dari tiga lantai. Candi Pendopo, menilik bentuknya dahulu merupakan bangunan terbuka dengan menggunakan tiang-tiang kayu sebagai penyangga atap dari ajuk, ilalang, genteng ? Hal tersebut dapat diketahui dari sederatan umpak batu yang terdapat di bagian atas bangunan tersebut. Pada bagian dinding pendopo yang dibuat dari batu andesit dihiasi dengan panil-panil relief cerita yang sebagian dapat diketahui judul 
ceritanya. Seperti cerita Tantri, Jarum Atat, Sang Satyawan, Panji, Sri Tanjung, Bubuksah,Gagangaking, dan masih ada beberapa panil relief yang belum dapat diidentifikasi namanya. Cerita-cerita yang menghiasi Candi Pendopo dari jenisnya diketahui terdapat pengaruh dari ajaran Budhis. Sementara itu, di Candi Induk lantai pertama terdapat cerita Ramayana, lantai kedua cerita Kresnayana, dan lantai ketiga cerita Garudeya. Dari ketiga unsur cerita tersebut, diketahui mendapat pengaruh dari unsur-unsur ajaran Hindu.

Dilihat bentuk dan unsur cerita yang menarik untuk wisatawan adalah cerita yang dilukiskan pada Candi Pendopo. Semua jenis

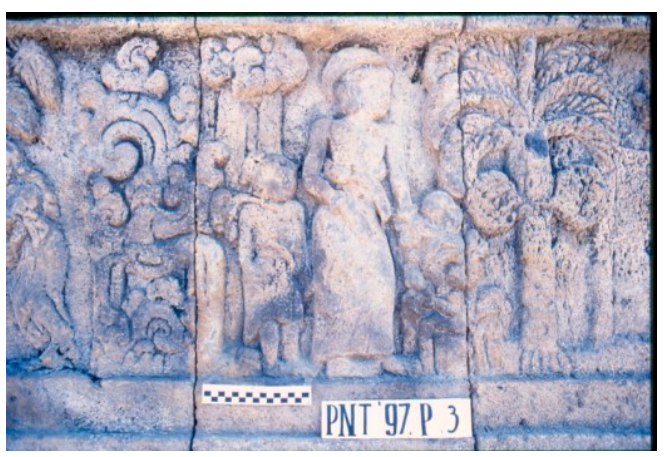

FOTO 3. Cerita Panji di lantai Candi Pendopo. Perjalanan Raden Panji melewati hutan dengan dua orang ponokawan untuk menemui Dewi Sekartaji. Dok. Balar YK. cerita yang dilukiskan sangat menarik untuk diketahui isi dan maknanya bagi kehidupan manusia, sebagai contoh adalah kisah tentang Sri Tanjung, yaitu kisah asmara yang populer di Jawa Timur sekitar abad XIV pada masa akhir Majapahit tentang seorang Bangsawan bernama Raden Panji Asmarabangun dengan Galuh Candrakirana (Dewi Sekartaji). Selain cerita tentang kisah cinta tersebut, tokoh Panji selalu digambarkan memakai penutup kepala (topi) dengan bentuk semacam helm yang dinamakan tekes. Berdasarkan pada beberapa studi yang telah dilakukan tentang siapa sebenarnya tokoh Panji yang selalu tampil dengan khasnya tampilan tokoh Panji dalam ukiran adalah topi, kelihatannya seperti helm motor, dan sering disebut 'tekes' (Nurcahyo, 2009: 26). Diidentifikasikan bahwa Panji adalah salah satu tokoh lokal (Indonesia asli), khususnya Jawa Timur.

Dalam Foto (3) digambarkan tokoh Panji memakai penutup kepala bentuknya seperti topi (tekes) sedang berjalan dengan diiringi oleh dua orang abdi laki-laki berbadan pendek, sedang melewati sebuah hutan untuk mencari kekasihnya Dewi Sekartaji ? Penggambaran hutan yang dilalui-pun menarik karena dapat diidentifikasi tentang beberapa jenis tanaman lokal/ asli Indonesia seperti pohon pinang/ jambe nama latin (areca cathechu) dan sukun. Sukun (artocarpus altilis) masing-masing memiliki fungsi dan magna sakral dan profan yang berkaitan dengan daerah angker dan untuk konsumsi sehari-hari. Sementara itu, di kalangan masyarakat jawa Timur, kisah asmara Sang Panji dengan Dewi Sekartaji, selalu menarik perhatian dan digemari sampai sekarang, bahkan sering ditampilkan dalam berbagai kesempatan perayaan pesta pada saat seseorang sedang melakukan hajatan dalam pentas seni pertunjukan.

\section{Relief di Museum Trowulan}

Di Museum Pusat Informasi Majapahit (PIM) Mojokerto, Jawa Timur terdapat beberapa buah relief yang menggambarkan bentuk desa, rumah dan permukiman pada masa Majapahit.

Salah satu relief yang dipilih sebagai contoh, adalah gambar relief tentang bentuk permukiman Foto (4). Dalam foto tersebut, menggambarkan bentuk sebuah pedesaan yang dibatasi oleh sungai, hutan, persawahan, dan pepohonan besar. Seperti pada umumnya batas sebuah desa pada saat ini, desa satu dengan desa lainnya selalu dengan batas-batas tertentu baik, alam, sungai dan tumbuhan. Desa pada masa Jawa kuna disebut wanua yang masing-masing harus mengurusi dan mencari pendapatan desa masing-masing yang dikelola untuk menjaga keamanan, dan melangsungkan jalannya peemrintahan desa. Oleh karena itu, batas antar desa ditandai dengan jelas, agar memudahkan dalam mengawasi dan menjaga ketertiban dan keamanan desa masing-masing.

Dari gambar panil relief tersebut, kemudian dapat ditarik suatu kesimpulan bahwa desa-desa pada masa Jawa kuna sudah tertata rapi dengan pembagian tata ruang yang 
lengkap, seperti lahan untuk perumahan/ permukiman terletak di tengah-tengah desa dengan pola permukiman konsentris, dibatasi dengan pagar-pagar. Sementara itu, dibagian luar permukiman digunakan untuk lahan pertanian/ sawah. Sungai-sungai besar di alirkan kesungai buatan dengan kanal-kanal kecil sebagai sumber mata air untuk mengaliri lahan pertanian. Gambar relief dengan sungai dan sawah membuktikan, bahwa pada masa Jawa Kuna telah memanfaatkan sumberdaya alam sekitarnya sebagai pelengkap sistem irigasi yang baik. Hal tersebut membuktikan penguasaan teknologi telah dkuasai oleh nenek moyang untuk mensiasati alam dan mengendalikannya.

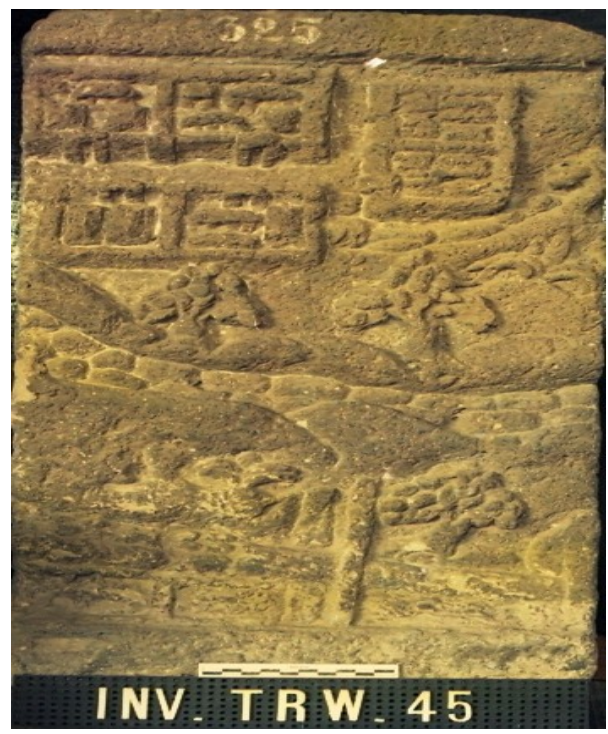

FOTO 4. Relief Bentuk Permukiman Masa Majapahit ? Tampak penggunaan tata lahan sebuah permukiman dengan dikelilingi oleh sungai pohon-pohon besar dan daerah areal pertanian yang subur. Koleksi PIM, Mojokerto.

\section{MANFAAT BAGI WISATAWAN}

Pemanfaatan kebudayaan sebagai objek wisata memang sangat menjanjikan dalam visi tahun 2020 World Tourism Organization (WTO) memprediksi bahwa wisata budaya akan merupakan salah satu di antara segmen pasar pariwisata di masa akan datang. Kiranya patut diingat bahwa ada semacam kekhawatiran antara manajemen kebudayaan termasuk juga alam dan kepariwisataan, dalam hal ini antara pariwisata, nilai budaya dan kelestarian benda cagar budaya (BCB). Dengan adanya kekhawatiran ini UNESCO menyambut pariwisata itu sebagai pedang bermata dua. Tentu pariwisata budaya dapat mendorong tradisi hidup kembali, pemugaran, pemeliharaan situs dan bangunan di satu pihak, tetapi di pihak lain pariwisata yang tak terkendali juga dapat menyebabkan dampak sebaliknya (Anom, 2001: 1). Dalam konteks tersebut, kurangnya perhatian masyarakat terhadap situs cagar budaya yang ada, mencoba menggali potensipotensi yang terpendam untuk dimanfaatkan kembali bagi kepentingan ekonomis, bahkan kepentingan adat/ tradisi. Upaya revitalisasi sumberdaya budaya tersebut, secara tak langsung dapat menghidupkan kembali tradisi-tradisi yang semula ada dan hampir punah ditelan oleh kemajuan/ modernisasi. Tradisi hidup merupakan warisan yang ditinggalkan oleh nenek moyang untuk tetap dilestarikan oleh generasi masa kini. Simbol-simbol dar tradisi tersebut dapat diacu dari tinggalan budaya materi (tangible) yang dapat diketahui dari relief.

Dalam suatu kasus pemanfaatan sumberdaya budaya arkeologis untuk dimanfaatkan oleh pariwisata adalah: seperti di Bali yang dikatakan oleh Ardika (2001: 3) sesuai dengan kondisi dan potensi daerah, salah satu aspek yang penting dikembangkan 
untuk mencapai tujuan pembangunan Bali adalah pariwisata budaya sebagai andalan dengan memanfaatkan potensi yang tersedia, termasuk tinggalan arkeologis sebagai sumberdaya budaya mempunyai nilai/ makna informasi atau Imu pengetahuan, estetika dan simbol-simbol tentang masa lalu, sehingga sering menjadi objek atau daya tarik bagi wisatawan yang pada akhirnya akan memberikan keuntungan ekonomi baik masyarakat maupun pemerintah. Tinggalan budaya tersebut, di daerah-daerah lain juga memiliki potensi yang dapat dikembangkan untuk pemanfaatan di sektor pariwisata.

Sumberdaya budaya satu daerah dengan daerah lainnya memiliki potensi yang berbeda-beda, tetapi masing-masing mempunyai nilai yang lebih atau keunggulan berdasarkan pada konteks budaya masing-masing. Jawa dan Bali memiliki banyak persamaan dalam hal objek dan daya tarik tinggalan budaya (arkeologis), berupa material culture/ budaya materi (tangible) maupun non-materi (intangible) yakni nilai-nilai luhur Obyek dan daya tarik wisata adalah, segala sesuatu yang menjadi sasaran wisata. Dalam bahasa Inggris istilah obyek dan daya tarik wisata ini digunakan atau disebut dengan attractions yang berarti segala sesuatu yang memiliki daya tarik, baik benda yang berbentuk fisik maupun nonfisik (Hamid, 1996: 27). Situs-situs arkeologis yang bersifat sakral, masih erat kaitannya dengan hubungan emosional dengan masyarakat pendukungnya, sehingga merupakan suatu siklus hidup yang sangat harmonis, dan menjadi daya tarik yang sangat kuat bagi wisatawan. Hal tersebut sangat berbeda dengan masyarakat Jawa, antara situs dengan masyarakat sekitarnya tidak ada hubungan emosional, sehingga situs tersebut kurang 'hidup'. Walaupun demikian, panilpanil relief candi di Jawa bisa memberikan informasi lengkap tentang gambaran kehidupan nenek moyang pada masa Jawa-Kuna. Oleh karena itu potensi yang ada pada relief candi-candi di Jawa dapat dimanfaatkan untuk menambah daya tarik wisatawan, khususnya bagi wisatawan minat khusus.

Pesan-pesan moral yang digambarkan dalam relief dapat diapresiasikan bagi ilmu pengetahuan, jatidiri dan dalam kehidupan manusia sehari-hari. Hal tersebut, kiranya penting karena dengan memberikan penjelasan secara jelas kepada wisatawan, sehingga memahami nilai-nilai luhur yang dikandung dalam kultur asli Indonesia. Bahwa sejak dahulu kala, Bangsa Indonesia telah mengutamakan hal-hal yang bernilai luhur (positif), untuk menjalin komunikasi antara sesama manusia, manusia dengan flora-fauna, dan manusia dengan alam sekelilingnya. Khasanah budaya tersebut dapat dibuktikan dari tinggalan budaya, sehingga informasi tersebut dapat diinteprestasikan dengan mengacu pada budaya dan tradisi yang masih dilestarikan oleh generasi masa kini, berupa adat-istiadat. Nenek moyang selalu mengharmonikan antara manusia dan alam lingkungan untuk menjaga kelestarian dan mencintai alam beserta isinya. Melalui studi relief dapat pula diketahui tentang jenis-jenis flora dan fauna asli Indonesia, maupun yang berasal dari luar Indonesia. Pada masa itu, bahkan telah terjadi domestikasi flora-fauna dari luar Indonesia yang digunakan untuk sarana transportasi (menarik gerobag/ sapi), dan peningkatan ekonomi dengan memanfaatkan sapi untuk ternak dan membajak sawah. Peristiwa tersebut, merupakan latar sejarah yang panjang telah memberikan gambaran, bahwa interaksi kontak budaya dan pertemuan antara dua atau lebih kebudayaan telah terjadi sejak ratusan, bahkan ribuan tahun yang lalu. Dalam setiap kontak budaya tersebut, budaya lokal masih mampu bertahan dan tetap memperlihatkan ciri khas Indonseia asli.

Seluruh potensi, latar sejarah dan kebudayaan yang terus berjalan sejak masa Jawa-Kuna sampai sekarang, merupakan mata rantai yang tidak terputus dengan segala macam perubahan dan perbedaan nilai-nilai yang terjadi. Latar budaya berupa nilai-nilai luhur tersebut, telah terbukti dapat bertahan hingga sekarang karena dilandasi oleh semangat dan jiwa yang menjunjung tinggi sifat-sifat persaudaraan dan semangat gotong-royong. Sifat kegotong-royongan merupakan nilai positif menarik untuk diketahui wisatawan minat khusus atau bagi yang ingin mengetahui lebih dalam tentang adatistiadat tempat yang dikunjunginnya. Mereka datang tidak hanya untuk melihat objek wisata, tetapi ingin mengetahui informasi yang lebih lengkap tentang latar budaya intangible suatu objek tertentu. Suatu objek cagar budaya (arkeologis) yang masih 
memiliki hubungan secara kontekstual dengan perilaku kehidupan masyarakat sekitarnya akan menjadi sangat menarik. Dalam hal ini terdapat hubungan emosional masyarakat dengan sebuah situs, sehingga perilaku masyarakat dalam mensiasati dengan lingkungan alam akan penuh dengan bermacam nilai-nilai simbolis untuk menjaga kelestarian situs, manusia dan alam sekitarnya. Hal tersebut merupakan siklus hidup saling sinergis yang dewasa ini sudah semakin langka, karena manusia tidak peduli lagi dengan alam lingkungan sekitarnya. Oleh karena itu, sebenarnya sebuah panil relief yang merupakan salah satu kmponen kecil sebuah candi, sebenarnya dapat memberikan sebuah informasi tentang aspek kehidupan manusia dan alam dari nenek moyang Indonesia.

Persoalan pokok dalam konteks ini adalah kemauan untuk memanfaatkan potensi sumberdaya budaya tersebut untuk diprogramkan dalam pendidikan dan kursus-kursus para pemandu wisata dalam tataran dan level-level tertentu. Lembaga-lembaga dan institusi arkeologis Indonesia siap untuk memberikan bermacam data dan informasi hasilhasil penelitian dan pengembangan yang telah dilakukan selama ini. Dalam hal ini kualitas SDM yang masih perlu ditingkatkan adalah pemberian pengetahuan tentang budaya, termasuk di dalamnya tata-krama, sopan-santun dalam pelayanannya. Pada dasarnya yang dimaksud dengan layanan prima (customer care) adalah kemampuan maksimal seseorang dalam berhubungan dengan orang lain dalam hal pelayanan. Memberikan pelayanan secara prima kepada pelanggan mempunyai tujuan untuk memenangkan persaingan (Sugiarto, 1999: 216) dengan kompetitor pariwisata negara lain yang mungkin masih mencari-cari jatidiri dan identitas bangsanya. Hal tersebut semuanya dimaksudkan untuk memberikan pelayanan yang maksimal terhadap dunia pariwisata. Wisatawan tidak sekadar datang dalam waktu singkat, tetapi karena banyak hal yang ingin diketahui, mereka jadi lebih lama untuk tinggal dan berinteraksi dengan masyarakat. Hal tersebut sebenarnya akan sangat menguntungkan sebagai sarana promosi tentang budaya Indonesia, sehingga tidak ada lagi klaim-klaim asset kebudayaan Indonesia yang diakui sebagai milik negara lain.

Di depan telah diilustrasikan dengan empat macam contoh relief yang masingmasing 'berisikan' informasi tentang: 1) Alat transportasi air sebagai negeri kepulauan Indonsesia asli dari sekitar abad VIII Masehi. Negeri kepulauan dengan air sebagai pembatasnya, diperlukan teknologi pembuatan alat transportasi air/ perahu. Perahuperahu Indonesia sudah sangat terkenal tangguh untuk melayari samudera (pinisi dan perahu bercadik); 2) Cerita fabel yang memuat tentang pesan-pesan moral, etika yang disajikan dengan jenaka, sesuai dengan sifat dan kepribadian orang Jawa yang sukabercanda-ria; 3) Adegan Cerita Panji Asmarabangun mengenakan pakaian dan topi ciri khas Indonesia asli, sebagai bentuk 'perlawanan' terhadap pengaruh asing, bahwa nenek moyang memiliki indentitas budaya yang adiluhung dan asli. Mengenai hal pemakaian tutup kepala bagi orang Indonesia rupanya sudah menjadi tradisi yang secara turun-temurun diwariskan, bahkan untuk ciri khas kenegaraan kita mengenal penutup kepala berupa peci yang berwarna hitam, sebagai identitas nasional; 4) Relief yang menggambarkan tentang pemanfaatan bentang lahan permukiman Jawa Kuna dengan lingkungan alam dan sumber-sumber air sebagai salah satu bentuk irigasi yang telah di kelola secara teratur dan terkonsep, di Bali sistem irigasi tradisional (subak atau atau organisasinya disebut karama subak) yang masih berlangsung sampai saat ini merupakan cerminan, bahwa dalam hal mengolah infra struktur teknologi pertanian, para nenek moyang telah berpengalaman. Dari contoh-contoh di depan, masih banyak lagi panil-panil relief yang dapat memberikan informasi tentang berbagai macam kebudayaan Indonesia atau Jawa asli, sebagai identitas dan jatidiri bangsa.

\section{PENUTUP}

Pariwisata erat kaitannya dengan wisata, yaitu kegiatan perjalanan dengan sukarela untuk menikmati obyek dan daya tarik wisata. Candi sebagai salah satu warisan budaya Hindu-Budha, bisa menjadi daya tarik yang dapat diandalkan bagi wisatawan domestik 
maupun mancanegara. Sesuai dengan tema pariwisata 2011 yaitu "Eco, Cultural, and MICE”. ECo merupakan bentuk kepedulian pariwisata Indonesia terhadap lingkungan. Culture menjadi harta dan kekuatan Indonesia yang memiliki kekayaan seni budaya beraneka ragam dari Sabang hingga Merauke. MICE (meeting, incentive, convention, dan exhibition). Oleh karena itu, pariwisata Indonesia yang berbasis pada budaya (culture) menjadi acuan dalam aspek manajerial pengelolaan yang berdasarkan pada pendekatan budaya. Dalam konteks tersebut, perlu ditingkatkan sarana, prasarana pendukung dari setiap objek wisata, utamanya objek-objek unggulan. Selain peningkatan sararaprasarana tersebut, upaya yang perlu dilakukan adalah penyiapan sumberdaya manusia yang berkualitas dan memilki etika ketimuran, santun dan ramah dalam setiap pelayanan yang diberikan.

Sumbangan dari potensi sumberdaya arkeologi berupa panil-panil relief yang selama ini masih belum maksimal digarap, dapat dimanfaatkan bagi 'dunia pariwisata', sehingga akan menambah pesona dan daya tarik wisatawan khususnya minat khusus, agar lebih mengenal dan mencintai budaya asli Indonesia. Hal tersebut, dapat sekaligus sebagai ajang promosi atau diplomasi budaya Indonesia khususnya 'kehidupan masa Jawa Kuna' yang beberapa unsur tradisi dan nilai-nilai tinggi masih tetap dilestarikan oleh warga dan masyarakat Jawa. Gambar/ tatahan ukiran relief menyimpan bermacam makna-makna simbolis, sebagai pranata sosial yang harus diikuti dan penggambaran kehidupan masyarakat Jawa-Kuna. Wisatawan yang berkunjung akan memperoleh gambaran yang lengkap (holistik) tentang objek yang dikunjungi, maupun dengan melihat sendiri atau mendapat informasi-informasi yang berkenaan dengan filosofi masyarakat. Oleh karena itu, sudah saatnya perlu dilakukan upaya kerjasama dan koordinasi tentang hasil-hasil kajian arkeologis, kajian ilmu budaya lainnya untuk dimanfaatkan dan disinergikan dalam sebuah kerangka kerja (frame work) untuk menjadi salah satu daerah tujuan wisata favorit dunia. Strategi tersebut merupakan suatu langkah nyata, karena pada dasarnya objek wisata yang dilihat bukan pada fisiknya tetapi informasi/ cerita yang ada dibaliknya justeru merupakan 'roh' yang akan sagat menarik perhatian bagi wisatawan, khususnya wisatawan yang mencari kepuasan batin di negeri tropik yang penuh dengan nuansa budaya.

Slogan-slogan yang dipromosikan oleh Kementerian Pariwisata dan Ekonomi Kreatif akan menjadi nyata, apabila dapat dirasakan manfaatnya oleh masyarakat, secara sosio, ekonomi, dan budaya. Oleh karena itu, melalui slogan "Wonderful Indonesia" yang menggambarkan daya tarik masyarakatnya, budayanya, makanannya, investasinya, dan alamnya. Pemerintah dengan seluruh masyarakat bersama-sama membangun dunia baru yaitu 'Dunia Pariwisata Indonesia' berbasis budaya yang adi luhung.

\section{KEPUSTAKAAN}

Andriani, Dian. I Gede Pitana. (2011) Ekowisata: Teori, Aplikasi, an Implikasi. Jurnal Kepariwisataan Indonesia. Vol.6, No2, Juni, hal 119 - 132. Pusat Penelitian dan Pengembangan Kepariwisataan. Badan Pengembangan Sumber Daya Kebudyaan dan Pariwisata. Kemenbudpar. Jakarta.

Anom, I Gusti Ngurah, 2001. Keberagaman Budaya Daerah Sebagai Potensi Pariwisata, Paper.

Ardika, Gede, 2001. Paradigma Baru ariwisata Kerakyatan Berkesinambungan. Jakarta, Kantor Menteri Negara Kebudayaan dan Pariwisata.

Hamid, Chalik. H.E.A. (1996). Pengetahuan Pariwisata, Yayasan Bhakti Membangun, Jakarta. 
Lelono. Hari. (1999) Pakaian dan Stratifikasi Sosial Masa Klasik Pada Relief Candi-Candi di Jawa Tengah, DI. Yogyakarta dan Jawa Timur. Laporan Penelitian Arkeologi (LPA). Balai Arkeologi Yogyakarta.

Nurcahyo, Henri. (2009). Konservasi Budaya Panji. Dewan Kesenian Jawa Timur, Surabaya.

Siswanto. (2000). Eksplorasi Sumberdaya Flora dan Fauna Oleh Masyarakat Jawa Kuna. Laporan Penelitian Arkeologi (LPA). Balai Arkeologi Yogyakarta.

Sugiarto, Endar. (1999). Psikologi Pelayanan Dalam Industri Jasa. Gramedia Pustaka Utama, Jakarta.

Diunduh pada tanggal 28 September 2011 dari Google. Mediadatariset. (Maret 2011). Penawaran Daftar Peraturan Hotel dan Pariwisata. PT Media Data Riset, Jakarta. 
